4 Jarvis MJ, Russell MAH, Saloojee Y. Expired air carbon monoxide: a simple breath test of tobacco smoke intake. Br Med f 1980;281:484-5.

${ }^{5}$ Feyerabend C, Russell MAH. Assay of nicotine in biological materials: sources of contamination and their elimination. 7 Pharm Pharmacol $1980 ; 32: 178-81$.

6 Feyerabend C, Russell MAH. A rapid gas-liquid chromatographic determination of cotinine in biological fluids. Analyst $1980 ; 105: 998-1001$

${ }^{7}$ Russell MAH, Raw M, Taylor C, Feyerabend C, Saloojee Y. Blood nicotine and carboxyhemoglobin levels after rapid-smoking aversion therapy. $\mathcal{F}$ Consult Clin Psychol 1978;46:1423-31.

${ }^{8}$ Russell MAH. Tobacco dependence: is nicotine rewarding or aversive ? In: Krasnegor NA, ed. Cigarette smoking as a dependence process. Washington DC: US Government Printing Office, 1979:100-22. (National Institute of Drug Abuse research monograph, No 23.)

' US Surgeon General. Smoking and health. Washington DC: US Government Printing Office, 1979:1-29. (DHEW report, No (PHS)79-50066.)

10 Smith JF, Mince HA, Hopkins KP, Bell J. Snuff-dipper's lesion: a cytological and pathological study in a large population. Arch Otolaryngol 1970;92:450-6.

11 Blot WJ, Fraumeni JF. Geographic patterns of oral cancer in the United States: etiologic implications. 7 Chronic Dis 1977;30:745-57.

12 Winn DM, Blot WJ, Shy CM, Pickle LW, Toledo A, Fraumeni JF. Snuff dipping and oral cancer among women in the Southern United States. $N$ Engl f Med $1981 ; 304: 745-9$.

${ }^{13}$ Hecht SS, Ornaf RM, Hoffmann D. Chemical studies on tobacco smoke, XXXIII. N'-nitrosonornicotine in tobacco: analysis of possible contributing factors and biologic implications. Fournal of the National Cancer Institute 1975;54:1237-44.

14 Hoffmann D, Raineri R, Hecht SS, Maronpot R, Wynder EL. A study of tobacco carcinogenesis, XIV. Effects of $\mathrm{N}^{\prime}$-nitrosonornicotine and $\mathrm{N}^{\prime}$-nitrosonanabasine in rats. Fournal of the National Cancer Institute $1975 ; 55: 977-81$.

(Accepted 15 fuly 1981)

\title{
Sister chromatid exchange induced by anti-herpes drugs
}

\author{
J J CASSIMAN, E DE CLERCQ, A S JONES， R T WALKER, H VAN DEN BERGHE
}

\begin{abstract}
The rate of sister chromatid exchange induced by several anti-herpes agents was measured to assess their potential mutagenicity. The agents-5-iodo-deoxyuridine (IDU), 5trifluoromethyl-deoxyuridine (TFT), and [E]-5-(2bromovinyl)-deoxyuridine (BVDU)-were incubated at various concentrations with human lymphocytes and fibroblasts, and the rate of sister chromatid exchanges was measured. In lymphocytes and fibroblasts BVDU and IDU did not induce exchange except at concentrations of $50 \mathrm{mg} / 1$, while TFT increased the rate of exchange at a concentration of $0.5 \mathrm{mg} / 1$.

The rate of sister chromatid exchange is a sensitive index of chromosomal damage, and these findings provide information on the safety of some of the antiherpes agents tested. TFT increased the rate of exchange at a concentration that coincides with its minimal antiviral concentration, but BVDU did not induce exchange at therapeutic concentrations.
\end{abstract}

\section{Introduction}

Various 5-substituted 2'-deoxyuridines, such as 5-iodo-deoxyuridine (IDU), 5-trifluoromethyl-deoxyuridine (TFT), and [E]-5-(2-bromovinyl)-deoxyuridine (BVDU), are being used or considered for use in the chemotherapy of herpes simplex and

$\overline{\text { Division of Human Genetics, University of Leuven, B-3000 Leuven, }}$ Belgium

J J CASSIMAN, MD, PHD, professor of developmental biology

H VAN DEN BERGHE, MD, PHD, professor of human genetics

Rega Institute for Medical Research, University of Leuven, B-3000 Leuven, Belgium

E DE CLERCQ, MD, PHD, professor of microbiology

Chemistry Department, Birmingham University, Birmingham B15 2TT

A S JONES, PHD, professor of chemistry

R T WALKER, PHD, lecturer of chemistry zoster virus infections. There are also several other 5-substituted deoxyuridine derivatives, such as 5-vinyl-deoxyuridine (VDU), which show significant anti-herpes activity, but these compounds do not appear to be sufficiently selective in their antiviral action. From comparative studies of the potency and cytotoxicity of these compounds in cell culture, BVDU has emerged as the most potent and most selective anti-herpes agent. ${ }^{1}$

Since IDU, TFT, and BVDU are all thymidine analogues, they might act as mutagens and hence induce permanent changes in the cellular genome. Sister chromatid exchange is a sensitive indicator of mutagenesis. ${ }^{2}$ We therefore examined IDU, TFT, and BVDU for their capacity to induce sister chromatid exchange in human lymphocytes and fibroblasts.

\section{Methods}

Sister chromatid exchange was scored as described previously. ${ }^{3}$ IDU was from Ludeco (Brussels) and TFT from Sigma Chemical Co, and BVDU was synthesised as described. ${ }^{1}$ VDU, 5-vinyluridine, and 5 -vinyluracil were included as reference materials. ${ }^{1}$

The nucleoside analogues were incubated for 48 hours with human (peripheral blood) lymphocytes and 72 hours with human (fetal lung) fibroblasts at concentrations ranging from 0.05 to $50 \mathrm{mg} / 1$ in the presence of $3 \mathrm{mg} / \mathrm{l}$ bromo-deoxyuridine. Ethylmethane sulphonate (Sigma Chemical Co) served as a positive control: it was added at 60 $\mathrm{mg} / \mathrm{l}$, a concentration known to induce a significant increase in the number of sister chromatid exchanges. ${ }^{3}$

\section{Results}

In lymphocytes BVDU and IDU did not increase the number of sister chromatid exchanges until the concentration was raised to 50 $\mathrm{mg} / \mathrm{l}$ (see table). TFT, however, caused a significant increase in the exchange rate at a concentration of $0.5 \mathrm{mg} / 1$; and at $5 \mu \mathrm{g} / \mathrm{ml}$ it proved even more effective in inducing exchange than the standard mutagen ethylmethane sulphonate.

While not very effective in lymphocytes, VDU turned out to be an exquisitely potent inducer of exchange in fibroblasts, where it caused a significant increase in exchange frequency at concentrations of 0.5 and $5 \mathrm{mg} / \mathrm{l}$, while BVDU and IDU failed to do so. BVDU and IDU increased the frequency of exchange in fibroblasts only at a concentration of $50 \mathrm{mg} / 1$.

The level of significance was assessed by Student's $t$ test, and, since the individual values were not distributed normally, significance was also monitored by the Poisson distribution. 
Induction of sister chromatid exchange in human lymphocytes and fibroblasts

\begin{tabular}{|c|c|c|c|c|c|c|c|c|c|c|c|c|}
\hline \multirow{2}{*}{$\begin{array}{c}\text { Concentration } \\
(\mathrm{mg} / \mathrm{l})\end{array}$} & \multicolumn{6}{|c|}{ Lymphocytes } & \multicolumn{6}{|c|}{ Fibroblasts } \\
\hline & BVDU & IDU & TFT & VDU & $\begin{array}{l}\text { 5-vinyl- } \\
\text { uridine }\end{array}$ & $\begin{array}{l}\text { 5-vinyl- } \\
\text { uracil }\end{array}$ & BVDU & IDU & $\mathrm{TFT}$ & VDU & $\begin{array}{l}5 \text {-vinyl- } \\
\text { uridine }\end{array}$ & $\begin{array}{c}\text { 5-vinyl- } \\
\text { uracil }\end{array}$ \\
\hline $\begin{array}{l}0 \\
0 \cdot 05 \\
0 \cdot 5 \\
5 \\
50\end{array}$ & $\begin{array}{c}8.5 \\
\text { NT } \\
7 \cdot 4 \\
6.95 \\
12 \cdot 45 \dagger\end{array}$ & $\begin{array}{c}6 \cdot 5 \\
\text { NT } \\
8 \cdot 3 \\
7 \cdot 3 \\
14 \cdot 33^{*} \dagger\end{array}$ & $\begin{array}{c}7 \cdot 04 \\
9 \cdot 55 \\
9 \cdot 85 \S \\
21 \cdot 75^{*} \dagger \\
\text { NT }\end{array}$ & $\begin{array}{l}6 \cdot 75 \\
6 \cdot 45 \\
8 \cdot 25 \\
9 \cdot 4 \ddagger \\
\text { NT }\end{array}$ & $\begin{array}{l}6 \cdot 35 \\
\text { NT } \\
7 \cdot 1 \\
6 \cdot 1 \\
8 \cdot 7\end{array}$ & $\begin{array}{l}7.6 \\
\text { NT } \\
5.6 \\
6.65 \\
6.90\end{array}$ & $\begin{array}{l}5 \cdot 45 \\
\text { NT } \\
7 \cdot 4 \\
7 \cdot 45 \\
12 \cdot 55^{*+}\end{array}$ & $\begin{array}{c}6 \cdot 7 \\
\text { NT } \\
6 \cdot 2 \\
7 \cdot 8 \\
10 \cdot 75\end{array}$ & $\begin{array}{r}5 \cdot 75 \\
6 \cdot 35 \\
8 \cdot 0 \ddagger \\
12 \cdot 1 \dagger \\
\text { NT }\end{array}$ & $\begin{array}{c}5 \cdot 55 \\
9 \cdot 25^{+} \\
22 \cdot 7^{*+} \\
39 \cdot 25^{*}+ \\
\text { NT }\end{array}$ & $\begin{array}{l}6.25 \\
N T \\
4.95 \\
5.75 \\
6.55\end{array}$ & $\begin{array}{l}6.90 \\
\text { NT } \\
5 \cdot 15 \\
6.55 \\
8.25\end{array}$ \\
\hline $\begin{array}{l}0+\text { Ethylmethane } \\
\text { sulphonate } \\
(60 \mathrm{mg} / 1)\end{array}$ & $16 \cdot 6 * \dagger$ & $15 \cdot 75^{*}+$ & $18 \cdot 4 * \dagger$ & $17 \cdot 80^{*} \dagger$ & $16.45^{*} \dagger$ & $15 \cdot 75^{*} \dagger$ & $13 \cdot 25 * \dagger$ & $14.65^{*}+$ & $12 \cdot 85^{*} \dagger$ & $13 \cdot 75^{*}+$ & $16 \cdot 75^{*} \dagger$ & $15 \cdot 3 * \dagger$ \\
\hline
\end{tabular}

At least 20 metaphases were examined in each case. In lymphocytes only four metaphases were scored for $50 \mathrm{mg} / 1 \mathrm{IDU}$ because of the presence of most cells in third mitosis. In fibroblasts only four metaphases were scored for $50 \mathrm{mg} / \mathrm{I}$ IDU and $5 \mathrm{mg} / \mathrm{l}$ VDU because of cellular toxicity of the compounds at these concentrations.

NT $=$ Not tested.

NT $=$ Not tested.
* Significant at 0.05 level of Poisson distribution.

Significant at $¥ 0.001, \ddagger 0.01$, or $\$ 0.05$ level of Student's $t$ test.

\section{Discussion}

The effects of the deoxyuridine derivatives in inducing sister chromatid exchange may be considered specific, since the free base (5-vinyluracil) and ribosyl counterpart (5-vinyluridine) of the most effective inducer (VDU, in fibroblasts) did not affect the rate of exchange in either lymphocytes or fibroblasts. These findings also indicate that 5-vinyluracil and 5-vinyluridine are not converted to VDU in these cells.

The efficiency of VDU as an inducer of sister chromatid exchange may be linked to its ability to be incorporated into DNA. The presence of 5-vinyluracil residues in DNA affects the $\gamma$-radiation sensitivity of phage DNA molecules, ${ }^{4}$ and a similar situation may occur with eukaryotic DNA. When incorporated into DNA 5-vinyluracil may participate in crosslinking reactions, as has been postulated previously for 5hydroxymethyluracil, and these cross links may be directly responsible for the phenomenon of sister chromatid exchange. In keeping with this hypothesis is the observation that mitomycin $\mathrm{C}$, being the prototype of the cross-linking agents, is also an excellent inducer of chromatid exchange. ${ }^{2}$

Our results cast some doubt on the selectivity and safety of TFT as an antiviral drug, since this compound increased the rate of sister chromatid exchange at a concentration $(0.5 \mathrm{mg} / \mathrm{l})$ that coincides with its minimal antiviral concentration. ${ }^{1}$ This is particularly important since TFT is now generally available (as a $1 \%$ ophthalmic solution) for the topical treatment of herpetic keratitis and may supersede IDU for that purpose. In marked contrast to TFT, BVDU did not significantly alter the rate of sister chromatid exchange until it was used at a concentration of $50 \mathrm{mg} / \mathrm{l}$, which is approximately 5000 times higher than its minimal antiviral concentration ${ }^{1}$ and 50 times higher than the blood drug concentrations achieved after oral administration at the recommended dose of $7.5 \mathrm{mg} / \mathrm{kg} /$ day. ${ }^{5}$ Since the rate of sister chromatid exchange represents a very sensitive index of chromosomal damage, it may seem wise to limit the clinical use of anti-herpes agents to doses that do not induce such exchange.

We thank $M$ Vienne for her expert technical help. This investigation was supported by a NATO Research Grant (to EDC and RTW).

\section{References}

1 De Clercq E, Descamps J, Verhelst G, et al. Comparative efficacy of antiherpes drugs against different strains of herpes simplex virus. $\mathcal{F}$ Infect Dis 1980;141:563-74.

2 Carrano AV, Thompson LH, Lindl PA, Minkler JL. Sister chromatid exchanges as an indicator of mutagenesis. Nature $1978 ; 271: 551-3$.

${ }^{3}$ Nicholas $\mathrm{AH}$, Vienne $\mathrm{M}$, Van den Berghe $\mathrm{H}$. Induction of sisterchromatid exchanges in cultured human cells by an organophosphorous insecticide: Malatbion. Mutat Res 1979;67:167-72.

4 Chelton ETJ, Duggan M, Hunston RN, et al. Incorporation of 5substituted vinyl derivatives into nucleic acids. The isolation and $\gamma$ radiation-sensitivity of bacterial phage $T 3$ containing the Thymine analogue 5-vinyluracyl. Biochem f 1980;187:257-60.

5 De Clercq E, Degreef H, Wildiers J, et al. Oral (E)-5-(2-bromovinyl)-2'deoxyuridine in severe herpes zoster. $\mathrm{Br} \mathrm{Med} \mathcal{f} 1980 ; 281: 1178-80$.

(Accepted 2 fuly 1981)

\section{OF MELANCHOLY.}

MELANCHOLY is that ftate of alienation or weaknefs of mind which renders people incapable of enjoying the pleafures, or performing the duties of life. It is a degree of infanity, and often terminates in abfolute madnefs.

CAUSES.- Iit may proceed from a hereditary difpofition; intenfe thinking, efpecially where the mind is long occupied about one object; violent paffions or affections of the mind, as love, fear, joy, grief, over-weening pride, and fuch like. It may alfo be occafioned by exceffive venery; narcotic or ftupefactive poifons; a fedentary life; folitude; the fuppreffion of cuftomary evacuations; acute fevers, or other difeafes. Violent anger will change melancholy into madnefs; and exceffive cold, efpecially of the lower extremities, will force the blood into the brain, and produce all the fymptoms of madnefs. It may likewife proceed from the ufe of aliment that is hard of digeftion, or which cannot be eafily affimilated; from a callous ftate of the integuments of the brain, or a drynefs of the brain itfelf. To all which we may add gloomy or miftaken notions of religion.

SYMPTOMS. - When perfons begin to be melancholy, they ate timorous; watchful; fond of folitude; fretful; fickle; captious and inquifitive; folicitous about trifles; fometimes niggardly, and at other times prodigal. The body is generally bound; the urine thin, and in $\frac{Z}{O}$ fmall quantity; the ftomach and bowels inflated with wind; the complexion pale; the pulfe flow and weak. The functions of the mind are alfo greatly perverted, in fo much that the patient often imagines himfelf dead, or changed into fome other animal. Some have imagined their bodies were made of glafs, or other brittle fubftances, and were afraid to move, left they fhould be broken to pieces. The unhappy patient, in this cafe, unlefs carefully watched, is apt to put an end to his own miserable life.

WHEN the difeafe is owing to an obftruction of cuftomary evacuations, or any bodily diforder, it is eafier cured than when it proceeds from affections of the mind, or an hereditary taint. A difcharge of blood from the nofe, loofenefs, fcabby eruptions, the bleeding piles, or the menses, fometimes carry off this difeafe.

(Buchan's Domestic Medicine, 1786.) 